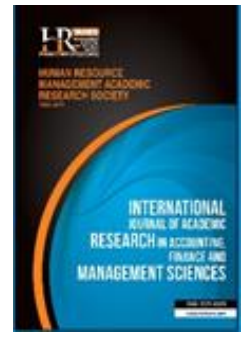

International Journal of Academic Research in Accounting, Finance and Management Sciences

Vol. 10, No.1, January 2020, pp. 261-269

E-ISSN: 2225-8329, P-ISSN: 2308-0337

(c) 2020 HRMARS

www.hrmars.com

To cite this article: Nawi, H. M., Yahaya, M. N., Cha, N. A., Kumar, R., Zulkefle, W. N. S. A. (2020). Goods and Services Tax Revisited: Tax Compliance among the Malaysian Public, 2015-2018, International Journal of Academic

\title{
Goods and Services Tax Revisited: Tax Compliance among the Malaysian Public, 2015-2018
}

\author{
Hafizah Mat Nawi ${ }^{1}$, Mohd Nor Yahaya ${ }^{2}$, Norlela Awang Cha ${ }^{3}$, \\ Rajespari Kumar ${ }^{4}$, Wan Nur Shawatul Aswal Zulkefle ${ }^{5}$ \\ 1,2National Defence University of Malaysia, ${ }^{1}$ E-mail: hafizah.matnawi@upnm.edu.my (Corresponding author) \\ ${ }^{3,4,5}$ Quest International University, Perak, Malaysia
}

\begin{abstract}
This study investigates factors that influence tax compliance among the Malaysian public with the implementation of Goods and Services Tax (GST) from 2015 to 2018. In particular, the effect of tax compliance on both tax knowledge and tax morale was examined. This study also examined the mediating effect of tax awareness on the above relationships. This research was centred on a survey of 400 taxpayers in Peninsular Malaysia. The data was analysed using multiple regression analysis. The results depict significant relationships between the variables, thus all proposed hypotheses were accepted. The results support both the Attribution Theory and the Theory of Planned Behaviour. This study offers meaningful insights into tax compliance and the relevant tax implementation for taxpayers and policymakers. Additionally, a model that can be tested in other jurisdictions was also proposed. The findings should increase taxpayer awareness of the importance of tax knowledge, as well as help policymakers draft appropriate tax policies.
\end{abstract}

Key words Attribution Theory, Goods and Services Tax (GST), Tax Compliance, Tax Knowledge, Tax Morale, Tax Awareness, Theory of Planned Behaviour

Received: 01 Mar $2020 \quad$ (C) The Authors 2020

Revised: 23 Mar 2020 Published by Human Resource Management Academic Research Society (www.hrmars.com)

Accepted: 25 Apr 2020 This article is published under the Creative Commons Attribution (CC BY 4.0) license. Anyone may Published Online: $\quad 07$ May $2020 \quad \begin{aligned} & \text { reproduce, distribute, translate and create derivative works of this article (for both commercial and } \\ & \text { non-commercial purposes), subject to full attribution to the original publication and authors. The full }\end{aligned}$ terms of this license may be seen at: http://creativecommons.org/licences/by/4.0/legalcode

\section{Introduction}

Malaysia implemented a 6\% Goods and Services Tax (GST) effective 1 April 2015 to 31 August 2018 (Ismail, 2015). The GST was implemented to enhance the nation's revenue, improve the effectiveness and efficiency of the tax system, and to solve the weaknesses of the previous Sales and Services Tax (SST) (Nasir et al., 2015). The GST implementation may overcome the high occurrence of tax avoidance besides generating more income for the country (Ismail, 2015). According to Nasir et al. (2015), Malaysia has faced a budget deficit for many years since 1997 as a result of the Asian Financial Crisis. Thus, the government had to find ways to increase the nation's revenue to boost national development.

The GST implementation in Malaysia has attracted much criticism from various parties. Boonyarat (2014) asserted that most taxpayers in Malaysia are not willing to pay more tax because they are dissatisfied with the government's policy. Some are afraid that the GST would cause a price hike in all products and services. Moomal \& Zakaria (2014) pointed out that most Malaysians lack information on GST implementation and are unclear about its objectives. Consumers are excessively worried; even thinking that they would be charged 6\% GST for every cash withdrawal made from Automated Teller Machines 
(ATMs). This issue went viral on Twitter, the Blogosphere, Facebook, as well as other online sources, portraying the relatively low level of public awareness regarding the Malaysian GST system, and, in turn, indirectly impeding tax compliance.

Nasir et al. (2015) found that most of their study respondents were unwilling to support GST because they thought that it would cause inflation. Similarly, Ching et al. (2017) investigated the effect GST introduction on the owners of small and medium-sized enterprises (SMEs) in retail sectors. They found that the respondents negatively viewed the implementation of GST and the GST regulations mainly because of the cost increase to their business operations. The respondents have a tough time complying with the burdensome compliance cost. They viewed GST as one of the reasons for the economic uncertainty and the depreciation of the Malaysian Ringgit. Another study on the impact of GST implementation was conducted by Salleh et al. (2018). The study examined the on the impact of GST implementation on the Malaysian Takaful industry. The study used an inductive analysis of relevant sources to justify the GST implementation in Takaful. They argued about the possibility of the contravention between Shariah principles and the GST implementation since there were no proper guidelines relating to the interpretation of specific terms for Takaful practices.

Haron \& Ayojimi (2019) recently studied the impact of GST implementation on the Malaysian Stock Market Index and presented similar findings. The study used the daily closing prices of the Malaysian Stock Index and future markets for five years from June 2009 to November 2016. They found that the Malaysian stock market was less volatile than future markets before the government announced GST and vice versa. They concluded that the implementation of GST increased the price of goods and services and reduced household purchasing power.

There are several thoughts, opinions, reactions, and questions surrounding GST implementation. For example, why did these issues on GST arise? Do Malaysians have a deep understanding or awareness of the GST concept? What are the factors that shape tax awareness? However, very few studies have investigated these issues in developing countries. To address this gap, this research focused on GST compliance among Malaysian taxpayers. The research points out the factors that influence public compliance towards GST. The research aims to examine the relationship between the dependent variables (tax knowledge, tax morale, and tax awareness) and the independent variable (tax compliance).

\section{Literature review: Theoretical and empirical}

\subsection{Goods and Services Tax (GST) v. Sales and Service Tax (SST)}

Taxes, including GST, are recognised as one of the main sources of government income. The GST replaced Malaysia's Sales Tax (10\%) and Service Tax (6\%) (SST) beginning 1 April 2015 up to 31 August 2018. The Sales and Service Tax (SST) was re-imposed on 1 September 2018 to replace the GST. The GST was abolished as part of the election promise of Pakatan Harapan's Manifesto, which claimed GST to be a regressive broad-based consumption tax that burdens low-income and middle-income households. SST is widely known to have different inherent weaknesses including causing tax falling and compounding impacts, incomplete tax reliefs on exported products, transfer pricing and value shifting, etc. in the Ministry of Finance. GST can overthrow these weaknesses because it is a more straightforward multi-stage tax system that will indirectly help control illegal tax avoidance. The change in the tax system also aims to produce a steady source of revenue, via a more productive, business-friendly, straightforward, and highly capable tax system.

The implementation of GST could be viewed as a technique to diversify the sources of income for the government. The government can maintain its income flow and enhance its abilities to develop the country and improve the stability of the economy. Besides, the GST implementation could help the government increase national savings to prepare for future inflation. Malaysia applies three types of GST, namely the Standard Rate, Zero Rate, and Exempted Rate (Shaari et al., 2015). A 6\% GST is charged on goods and services with standard-rated supplies. Firms have to collect GST and pay it to the government. The zero rates of GST are charged on goods and services with zero-rated supplies. Firms can claim input tax credit when they bring in the stocks for supplies charged at zero rates of GST. Furthermore, the exempted GST rate is charged on those non-taxable goods and services, for example, basic food items such as flour, salt, 
sugar, and cooking oil; transportation services such as taxi, boat and train; and education and health services. Firms that bring in these supplies are not allowed to claim input tax credit (Shaari et al., 2015).

\subsection{Theoretical background}

This study tested two main theories, namely the Attribution Theory and the Theory of Planned Behaviour. The Attribution Theory discusses how individuals explain the causes of their behaviours or the behaviour of people around them (Kamil, 2015). It is a process of impression forming in which people make conclusions about the elements that influence their attitude. People are trying to find out the reasons for events that have happened. They are therefore considered amateur psychologists under this theory. Kamil (2015) added that a person's behaviour could be shaped by external or internal influences. People need to act according to the changes in the environment. A behaviour caused by internal influences is believed to be under the individual's control and vice versa. This theory is closely related to this study because the taxpayers' willingness to pay taxes is related to their perception of the tax itself. Their perception or judgement of a situation will be influenced by internal and external factors.

Alternatively, Fishbein \& Ajzen (1975) developed the Theory of Planned Behaviour (TPB), which emphasises that an individual's behaviour is due to his intentions to behave in that way. He will act according to what he believes is the most appropriate. Fishbein \& Ajzen (1975) stated that three factors determine human actions, namely, behavioural belief, normative belief, and control belief. Under behavioural belief, the human behaviour and evaluation of the behaviour stem from the individual's belief. A person's particular behaviour reflects how he feels (Ishak et al., 2015). His attitude will affect his intentions of performing or not performing a particular behaviour (Ishak et al., 2015). In other words, the taxpayers will be obedient to the tax rules if they are aware and are confident of the benefits of paying taxes.

On the other hand, normative belief is related to norms (Fishbein \& Ajzen, 1975). One's behaviour is tailored to the expectations of other people and the motivation to meet those expectations. It can also be perceived as a form of pressure from society to perform a particular behaviour. Normative belief is related to the satisfaction of the taxpayers regarding the tax system service as to whether or not it is effective and efficient and tax counselling. Furthermore, control belief is the belief of the presence of things that prohibit or support certain behaviour and the consciousness of the power of the things that prohibit or support the behaviour (Fishbein \& Ajzen, 1975). Tax penalties are made so that taxpayers are encouraged to pay taxes and will obey tax rules. The tax compliance level is therefore based on the taxpayers' awareness of how powerful tax penalties can be in compelling their obedience.

\subsection{Tax Compliance}

Tax compliance can be defined as the taxpayers' willingness to obey tax laws such as tax calculation, tax registration, tax declaration and tax payment, to achieve national economic equilibrium (Nguyen et al., 2020; Ngo et al., 2019). Many factors could determine taxpayers' willingness to abide by tax regulations, such as ethics, the legal environment, and other situational factors at a particular time and place. The taxabiding level will be lower if the tax systems are unfair. Kamil (2015) concluded that tax knowledge, tax penalties, tax services, as well as taxpayers' awareness significantly impact taxpayer compliance. Taxpayers demand to know the benefits of paying taxes before doing so to avoid any misunderstanding towards the tax that is implemented. Previous studies have shown that tax awareness is positively interrelated with tax compliance (Nur Pertiwi, 2013), asserting that an optimistic tax compliance result would depend on the taxpayer's attitude towards tax services and financial sanctions imposed by the tax authorities. In the same vein, Kirchler (2007) revealed that socio-psychological factors, perception, morale and motivation factors, as well as political and economic factors could also influence the tax compliance of individuals.

\subsection{Tax Knowledge}

Tax knowledge is something that can be learned via proper or informal education such as reading an article or news or asking someone to obtain a better understanding (Hastuti, 2014). It can also be gained via self-learning (Hastuti, 2014). Without proper knowledge or understanding of tax rules, people tend to not willingly pay taxes. Savitri (2015) asserted that taxpayers' awareness could be enhanced when they 
know how to calculate their taxes and how to pay their tax liability. A competent knowledge of tax could persuade the taxpayer to be wiser at paying tax (Oladipupo \& Obazee, 2016). Besides, it will also be easier for taxpayers to follow the tax rules if they are knowledgeable about the tax system (Nasir et al., 2015). Furthermore, Shaari et al. (2015) affirmed that the misunderstanding of new tax schemes could significantly be reduced with increased tax knowledge.

Additionally, Ramona-Anca \& Larissa-Margareta (2012) stressed that the taxpayers' formal or informal tax education, as well as many types of government assistance, could increase their level of awareness and help them endure the challenging GST environment. Saira et al. (2010) reiterated that the main reason for the citizens' resistance to GST implementation is the inconsistency in awareness and a lack of knowledge on GST. Boonyarat (2014) conducted Structural Equation Modelling (SEM) and found a positive association between tax knowledge and tax compliance, with the consideration of tax awareness. Similarly, Palil et al. (2013) used multiple regression analysis and found the same result. These results suggest that the proper inculcation and dissemination of tax knowledge to the public is one of the most fundamental ways to improve tax awareness as well as tax compliance.

\subsection{Tax Morale}

Tax morale is defined as "the attitude of a group or the whole population of taxpayers regarding the question of accomplishment or neglect of their tax duties; it is anchored in the citizens' tax mentality and in their consciousness to be citizens, which is the base of their inner acceptance of tax duties and acknowledgement of the sovereignty of the state" (Schmölders 1960). Luttmer \& Singhal (2014) explained tax morale as capturing the non-pecuniary motivations necessary to prepare taxpayers for tax compliance. An individual will feel shameful or guilty if they fail to pay or fulfil tax requirements. These individuals may pay tax due to mutual motivations such as in exchange for benefits provided to them or others. They may also choose to pay taxes although their income or profits would be higher if they opted not to pay (Luttmer \& Singhal, 2014).

Togler (2011) indicated that tax morale is significant to increase taxpayer awareness. This fact is true because an individual's motivation will affect his capability to increase his knowledge of tax information, especially during a discussion to exchange their knowledge or information. Their tax morale will be greatly improved when they are more aware that public resources are well spent and managed efficiently, and vice versa. At the same time, it will also encourage them to pay taxes when they have a better understanding of taxes (Barone \& Mocetti, 2011).

Based on the review of the literature, the present study posits the research questions and hypotheses below:

1. What are the factors that influence tax compliance among the Malaysian public? (Hypothesis 1 and Hypothesis 2)

Hypothesis 1 (H1): There is a positive association between tax knowledge and tax compliance.

Hypothesis 2 (H2): There is a positive association between tax morale and tax compliance.

2. Do tax knowledge and tax morale influence the tax awareness of Malaysian taxpayers? (Hypothesis 3 and Hypothesis 4)

Hypothesis $3(\mathrm{H} 3)$ : There is a positive association between tax knowledge and tax awareness.

Hypothesis 4 (H4): There is a positive association between tax morale and tax awareness.

3. Considering the mediating effect of tax awareness, do tax knowledge and tax morale influence the tax compliance of Malaysian taxpayers? (Hypothesis 5)

Hypothesis $5 a(\mathrm{H} 5 \mathrm{a})$ : There is a positive association between tax knowledge and tax compliance, mediated by tax awareness.

Hypothesis $5 b(\mathrm{H} 5 \mathrm{~b})$ : There is a positive association between tax morale and tax compliance, mediated by tax awareness. variables.

Figure 1 shows the research conceptual framework, which incorporates the above theories and 


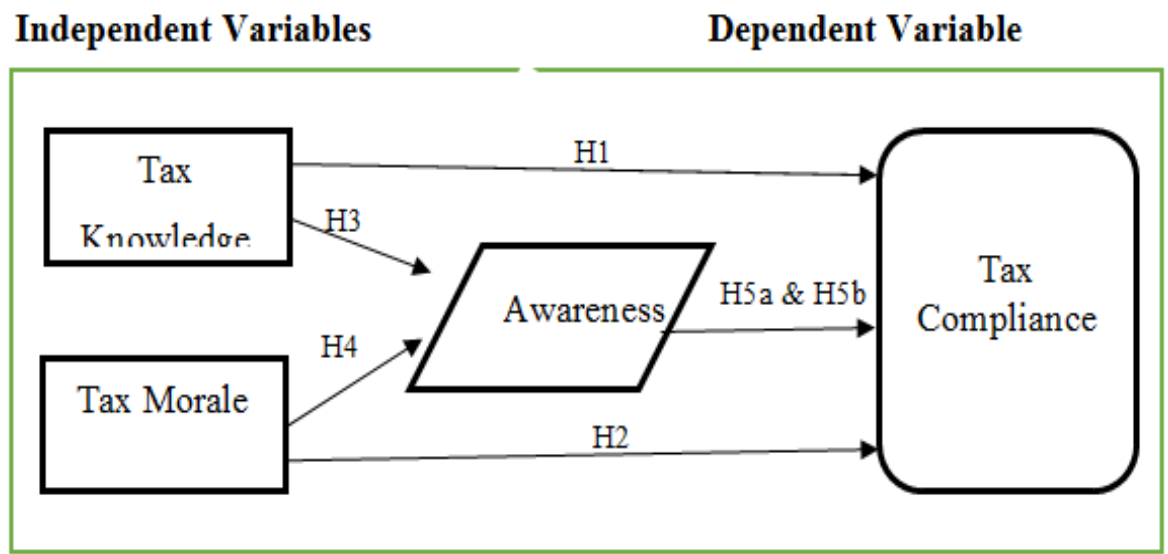

Figure 1. A conceptual framework for the study

\section{Methodology of research}

This research is a Positivist research. A personally-administered questionnaire survey was used as the instrument. The researchers personally administered the survey questionnaire to avoid non-response issues. The measurements of variables in the questionnaire were taken from previous literature. The study used convenience random sampling, as it is convenient, quick, and less expensive. All accessible GST taxpayers were chosen as subjects. The empirical works for this research were undertaken in the Northern Region of Malaysia. The Northern Region is the fourth largest region in Malaysia with a population of 673,318 people based on the World Population Review (2020).

To achieve the minimum sample size for generalisation per Krejcie \& Morgan (1970), and as cited by Collis \& Hussey (2013), the data collection of this study was conducted twice (due to insufficient data in the first stage). The processes comprised two parts: early respondents and late respondents. This study followed the recommendation of Collis and Jarvis (2002), which was to conduct an independent samples ttest. The analysis failed to detect a significant difference between early and late respondents for the demographic background. This study received 400 usable responses, yielding a response rate of 84 per cent.

Before the main survey, a pilot test was performed to clarify issues regarding the questionnaire. Reliability analysis was performed for the pilot data and the main data. Moreover, no data was excluded from the data screening regarding the data from the main survey. The researcher also screened the data to identify any likely problems from the ordinal and ratio variables using scatter diagrams. This study then performed an Exploratory Factor Analysis (EFA), Pearson's Correlation analysis, and Multiple Regression analysis. The multiple regression analysis was used to test the research hypotheses.

\section{Results and discussions}

\subsection{Frequency statistics}

Descriptive statistics were used to present the demographic information of the respondents. The result shows a slightly lower percentage of male respondents at $48.8 \%$ to female respondents with $51.2 \%$. Six age groups were involved. The largest number of respondents was between 25 and 29 years old, representing approximately $36.5 \%$ of the samples. In contrast, only $4.1 \%$ were 45 to 49 years old. The percentage of the three major ethnic groups was not significantly different, where each ethnic group made up more than $30 \%$ of the sample. The statistics also present the monthly income level of the respondents. Most of the respondents earned between RM2,500 and RM4,000 per month while the least number of respondents earned a monthly salary of RM6,000 and above. In terms of education level, $51.2 \%$ of the respondents had a Diploma or Bachelor's degree and less than $5 \%$ of the sample had a PhD. 


\subsection{Reliability Analysis}

This study adopted a reliability analysis to analyse the reliability and internal consistency of each variable. This study followed the standard estimation for the alpha coefficient of 0.70 , as suggested by Hair et al. (2010). The Cronbach's alpha for all variables was above 0.70 , indicating high reliability. For further examination of internal consistency, this study reaffirmed the reliability of each factor by looking at itemto-total correlations' and the 'alpha if items were deleted'. All were substantial at 0.001 levels. The item-tototal correlations were found satisfactory, as they were above the threshold value (0.35). Besides, no variables were omitted from the subsequent analysis, as the 'alpha if items were deleted' was less than the overall reliability.

\subsection{Exploratory Factor Analysis}

There are three groups of variables in this research. Each group contains five items. The KMO measure for all items in each variable showed either meritorious or mediocre sample adequacy (Kaiser, 1974 cited by Vaus, 2002) with a value of 0.818 for tax knowledge, 0.687 for tax compliance, and 0.826 for tax morale. Bartlett's Test of Sphericity supports the factorability of the correlation matrix, which reached statistical significance $(0.000)$. All the communalities of the variables were more than 0.5 , which means that all variables can be used and none of the variables had to be deleted.

\subsection{Pearson's Correlation Coefficient Analysis}

This study also generated a 2-tailed Pearson's correlation matrix for each set of predictor variables. The results indicate that the strength of the associations between tax awareness and each independent variable was moderate, as the correlation value ranged from 0.40 to 0.59 (Hair et al., 2010). The significance of the relationships between the variables was less than the alpha value of 0.01 . This result shows that the relationship between tax awareness and all independent variables is significant. This study also examined tolerance and variable inflation factors (VIFs). No variable was found to cause a problem. The results reveal that all variables are correlated so there was no multicollinearity issue.

Table 1. Pearson's Correlation Coefficient Analysis

\begin{tabular}{|c|c|c|c|c|}
\hline & TC & TK & TM & TA \\
\hline TC & 1 & $.551^{* *}$ & $.444^{* *}$ & $.329^{* *}$ \\
\hline TK & $.551^{* *}$ & 1 & $.325^{* *}$ & $.348^{* *}$ \\
\hline TM & $.444^{* *}$ & $.325^{* *}$ & 1 & $.419^{* *}$ \\
\hline TA & $.329^{* *}$ & $.348^{* *}$ & $.419^{* *}$ & 1 \\
\hline$* *$. Correlation is significant at the 0.01 level (2-tailed). \\
\hline
\end{tabular}

Note: $T A=$ Tax Awareness; $T K=$ Tax knowledge; $T C=$ Tax compliance; $T M=$ Tax morale

\subsection{Multiple Regression Analysis}

Furthermore, this study tested the hypotheses using multiple regression analysis. Table 2 summarises the results of the multiple regression analysis. This table also includes the proposed hypotheses and results.

Table 2. Results of the Regression Analysis

\begin{tabular}{|c|c|c|c|c|}
\hline $\begin{array}{c}\text { Independent Variable } \\
\begin{array}{c}\text { (Constant) }(\beta) \\
(\text { T-value })^{*}\end{array}\end{array}$ & $\begin{array}{c}\text { Dependent variable (TC) } \\
(.429)^{*}\end{array}$ & Hypothesis & Result & Remark \\
\hline TM & .350 & H2 & Positive; & Supported \\
& $(4.297)^{* * *}$ & Positive & significant & Supported \\
\hline TK & .605 & H1 & Positive; & significant \\
& $(6.402)^{* * *}$ & Positive & Positive; & Supported \\
\hline TK*TA & .432 & Positive & significant & \\
\hline
\end{tabular}




\begin{tabular}{|c|c|c|c|c|}
\hline Independent Variable & Dependent variable (TC) & Hypothesis & Result & Remark \\
\hline TM*T $^{*}$ TA & $\begin{array}{c}.411 \\
(5.212)^{* * *}\end{array}$ & $\begin{array}{c}\text { H5b } \\
\text { Positive }\end{array}$ & $\begin{array}{c}\text { Positive; } \\
\text { significant }\end{array}$ & Supported \\
\hline R-Squared & 0.59 .2 & & & \\
\hline F- (p-value) & $164.759(0.000)$ & & & \\
\hline
\end{tabular}

Note:

- $T C=$ Tax compliance; $T A=$ Tax Awareness; $T K=$ Tax knowledge; $T M=$ Tax morale

- Absolute value of $t$-statistics in parentheses, asterisks denote the level of significance

${ }^{*} p<0.05 ;{ }^{* *} p<0.01 ;{ }^{* *} p<0.001$.

The value of R-squared indicates that $59.2 \%$ of the variations in tax awareness can be explained by the independent variables (i.e. tax knowledge, tax compliance and tax morale). In other words, another $40.8 \%$ of the variations in tax awareness is explained by other predictors that were not included in the model.

Based on Table 2, a multiple linear regression equation was constructed as follows:

Tax compliance $=0.135+0.605$ (tax knowledge $)+0.432$ (tax knowledge*tax awareness $)+0.411$ (tax morale*tax awareness) +0.350 (tax morale)

This equation shows that tax knowledge greatly contributes to tax compliance $(\beta=0.605, p=0.000)$. Tax knowledge is mediated by tax awareness $(\beta=0.432, p=0.000)$ and tax morale is mediated by tax awareness $(\beta=0.411, p=0.000)$. The least influential factor was tax morale $(\beta=0.350, p=0.000)$. Since all associations are significantly associated with the dependent variable, hence, the four hypotheses are accepted. This finding is consistent with that of Oladipupo \& Obazee (2016), Nur Pertiwi (2013), Boonyarat et al. (2014), and Torgler (2011). Furthermore, the p-value associated with the F-statistic was 164.759. So, it can be concluded that the current regression equation meaningfully explains the relationship between tax compliance and the predictors. Overall, the regression model predicted tax compliance well, as the $p$-value was below 0.05 .

\section{Conclusions}

This study aimed to fill the gap in the literature by identifying all the factors affecting the Malaysian public compliance with GST. The multiple regression analysis conducted in this study confirmed that tax compliance positively influences tax knowledge and tax morale. The results also proved the mediating effects of tax awareness on the relationship between tax knowledge and tax morale, and tax compliance.

In other words, public awareness and compliance towards taxes would increase with increased tax knowledge. It was found that GST has transformed into a multi-stage consumption tax, with enormous procedural differences. Thus, this research recommends that the government conduct more campaigns and promotional efforts to stress the importance of reducing the budget deficit, focusing more on exemption lists instead of expansion lists. The government should also apply true and fair disclosure of its budget (e.g. by providing excellent health and education services) and then reviewing it on the regular to suit the needs of taxpayers. Furthermore, when people are aware that public resources are spent fairly and efficiently, their tax morale will be improved and thus a better attitude towards tax payments could be developed.

This research makes several important contributions to the existing field of tax awareness and tax compliance with relevant implementations to taxpayers, financial providers, and policymakers. The findings should increase the taxpayers' awareness of the importance of tax knowledge as well as help policymakers formulate appropriate tax policies. The government should provide proper guidelines for the public, particularly regarding the procedures for a sound and efficient implementation of GST. More importantly, the government should ensure that the revenues collected from GST are managed well and the income from GST is duly distributed for the benefit of all citizens, as enshrined in the Malaysian concept of 'rakyatcentred' government.

The limitation of the study presents opportunities for future research. As the sample is solely based on one region in the country, it may not be sufficient to generalise the findings to the entire population of Malaysian taxpayers. Essentially, future research is still needed to compare the taxpayers' awareness in the 
three main economic regions in Malaysia, particularly concentrating on firms rather than individual taxpayers.

Furthermore, future research could also investigate the advantages or disadvantages of implementing GST over SST or vice versa. For instance, the Malaysian government's initiative to implement GST over SST could have resulted in higher expendable income among the public due to lower prices imposed on most goods and services. SST will be more favourable to the B40 group since they are exempted from basic needs and goods tax. The SST allows citizens to obtain medical and pharmaceutical products without having to pay tax. Apart from that, taxes are also exempted for products such as diapers and sanitary pads, which have been a huge point of contention with the implementation of GST. The implementation of SST may also increase investments in real estate and property, as housing prices are expected to become more affordable since SST introduces tax exemptions for construction materials.

\section{References}

1. Asma, M., \& Zulkarnain, Z. (2014). Awareness, acceptance and expectations of Malaysian consumers towards Goods and Services Tax (GST). Journal of Contemporary Management Sciences, 4(2), 15-27.

2. Barone, G., \& Mocetti, S. (2011). Tax morale and public spending inefficiency. International Tax and Public Finance, 18(6), 724-749.

3. Boonyarat, N. (2014). The Antecedents of Taxpayers Compliance Behavior and the Effectiveness of Thai Local Government Levied Tax. IBT Journal of Business Studies (JBS), 10(1)

4. Ching, Y. M., Kasipillai, J., \& Sarker, A. (2017). GST compliance and challenges for SMEs in Malaysia. eJTR, 15, 457.

5. Collis, J., \& Hussey, R. (2013). Business research: A practical guide for undergraduate and postgraduate students. Macmillan International Higher Education.

6. Collis, J., \& Jarvis, R. (2002). Financial information and the management of small private companies. Journal of Small Business and Enterprise Development. 9(2), 100-110.

7. Fisbein, M., \& Ajzen, I. (1975). Belief, attitude, intention and behavior: An introduction to theory and research. Massachusetts, Addison-Wiley Publishing Company.

8. Hair, J. F., Black, W. C., \& Babin, B. J., \& Anderson, R. E. (2010). Multivariate data. Seventh edition. Prentice Hall, Upper Saddle River, New Jersey.

9. Haron, R., \& Ayojimi, S. M. (2018). The impact of GST implementation on the Malaysian stock market index volatility: an empirical approach. Journal of Asian Business and Economic Studies. 1-19. E-ISSN 2515-964X.

10. Hastuti, R. (2014). Tax awareness and tax education: A perception of potential taxpayers. International Journal of Business, Economics and Law, 5(1), 83-91.

11.Ishak, N. I., Othman, M. H., \& Omar, M. F. (2015). Students' perception towards the newly implemented Goods and Services Tax (GST) in Malaysia. International Journal of Contemporary Applied Sciences, 2(6), 80-99.

12.Ismail, N. A. (2015). Comparison between the effect of goods and services tax and wealth tax on low income households: A theoretical study. International Journal of Environment, Society \& Space, 3(2), 32-9.

13.Kamil, N. I. (2015). The Effect of Taxpayer Awareness, Knowledge, Tax Penalties and Tax Authorities Services on the Tax Compliance: (Survey on the Individual Taxpayer at Jabodetabek \& Bandung). Research Journal of Finance and Accounting, 6(2), 104-111.

14. Kirchler, E. (2007). The economic psychology of tax behaviour. Cambridge University Press.

15.Luttmer, E. F., \& Singhal, M. (2014). Tax morale. Journal of Economic Perspectives, 28(4). 149-68.

16.Nasir, N. B., Abdullah, A. B., Mohtar, N. B., \& Zainurdin, Z. B. (2015). Public Awareness Towards Goods and Service Tax (GST) in Kuala Lumpur, Malaysia. International Academic Research Journal of Social Science, 1(2), 101106.

17.Ngo, T. H., Vu, T. P. L., \& Thi, P. L. (2019). Determinants Affecting Tax Compliance: A Case of Enterprises in Vietnam. Academy of Accounting and Financial Studies Journal. 23 (3). 
18.Nguyen, T. T. D., Pham, T. M. L., Tam, T. L. E., Truong, T. H. L., \& Tran, M. D. (2020). Determinants Influencing Tax Compliance: The Case of Vietnam. Journal of Asian Finance, Economics and Business, 7(2), 65-73.

19.Pertiwi, N. D. (2013). The Influence of Tax Consciousness, Service Tax Authorities, and Tax Sanctions on Tax Compliance (Survey on Individual Taxpayer Conducting Business Operations and Professional Service In Jakarta). Journal of Chemical Information and Modeling, 53.

20.Oladipupo, A. O., \& Obazee, U. (2016). Tax knowledge, penalties and tax compliance in small and medium scale enterprises in Nigeria. IBusiness, 8(1), 1-9.

21.Palil, M. R., Akir, M. R., \& Ahmad, W. F. B. A. (2013). The perception of tax payers on tax knowledge and tax education with level of tax compliance: a study the influences of religiosity. ASEAN Journal of Economics, Management and Accounting, 1(1), 118-129.

22.Ramona-Anca, N., \& Larissa-Margareta, B. (2012). The implications of tax morale on tax compliance behavior. The Annals of the University of Oradea, 732.

23.Saira, K., Zariyawati, M. A., \& Yoke-May, L. (2010). An exploratory study of goods and services tax awareness in Malaysia, seminar on national resilience (SNAR): Political managements and policies in Malaysia, 13-15 July. Langkawi, Malaysia http://repo. uum. edu. my/3178/1 S, 14.

24.Salleh, M. C. M., Yussof, S. A., \& Abdullah, N. I. (2018). Impact of the Government Service Tax (GST) on the Malaysian Takaful Industry: Issues and Challenges. Advanced Science Letters, 24(5), 31783183.

25.Savitri, E. (2015). The Effect of Tax Socialization, Tax Knowledge, Expediency of Tax ID Number and Service Quality on Taxpayers Compliance with Taxpayers Awareness as Mediating Variables. Procedia-social and behavioral sciences, 211, 163-169.

26.Shaari, N., Ali, A., \& Ismail, N. (2015). Student's awareness and knowledge on the implementation of Goods and Services Tax (GST) in Malaysia. Procedia Economics and Finance, 31, 269-279.

27.Torgler, B. (2011). Tax morale and compliance: review of evidence and case studies for Europe. The World Bank.

28.Vaus, D. A. (2002). Surveys in Social Research. Psychology Press.

29.World Population Review. (2020).Malaysia Population Review. https://worldpopulation review.com/countries/malaysia-population/ 